\title{
Genetic Diversity of Fusarium solani f. sp. cucurbitae, the Causal Root and Crown Rot of Cucurbits (Melon) by Using Molecular Markers and Control
}

\section{Falah Abdul-Hasan, Halima Z. Hussein}

Plant Protection Department, College of Agriculture, University of Baghdad, Baghdad, Iraq

Email: Halimaalbahadly@yahoo.com, ffaall684@gmail.com

How to cite this paper: Abdul-Hasan, F. and Hussein, H.Z. (2016) Genetic Diversity of Fusarium solani f. sp. cucurbitae, the Causal Root and Crown Rot of Cucurbits (Melon) by Using Molecular Markers and Control. American Journal of Plant Sciences, 7, 2151-2172.

http://dx.doi.org/10.4236/ajps.2016.715191

Received: August 1, 2016

Accepted: November 1, 2016

Published: November 4, 2016

Copyright $\odot 2016$ by authors and Scientific Research Publishing Inc. This work is licensed under the Creative Commons Attribution International License (CC BY 4.0).

http://creativecommons.org/licenses/by/4.0/ (c) (i) Open Access

\section{Abstract}

Detection of F. solani f. sp. cucurbitae causal agent of the crown and root rot disease of melon race 1 , race 2 is difficult. It is based only on morphological characteristic. In this study, forty isolates identified as Fusarium solani based on morphological characterization, $F$. solani was one of the most frequently isolated species. Molecular identification of these isolates by PCR technique using species-specific primer, indicated that thirty-two isolates, amplified product $580 \mathrm{bp}$ (race 1) and two isolate amplified product $580 \mathrm{bp}$ (race 2), while six isolates were not amplified with primer of both races. Production of Trichothecenes (T2-toxen, DON.) by Fusarium solani was conducted on isolates confirmed as belonging in the F. solani by PCR. The results indicated that the presence of Tri5, Tri13 genes is coding the ability of synthesis mycotoxin. In vitro, the results indicated that NPs (AgNPs, MgNPs) and chemical (Phylex) possess the antifungal properties against at various level. Treatment with (AgNPs 150 ppm, MgNPs 2\%, 3\% ppm) and 3\% Phylex resulted in maximum inhabitation of $F$. solani. In vivo, five characters (height plant, hoot ant root fresh and dry weight) were measured based on the greenhouse, field experimental results. Treatment with (AgNPs, MgNPs) and Phylex had higher measured parameters than positive control.

\section{Keywords}

Fusarium solani f. sp. cucurbitae Race 1, Race 2, Crown and Root Rot of Melon, PCR Detection, Specific Primers, Mycotoxins, Antifungal Effect, AgNPs, MgNPs, Phylex 


\section{Introduction}

Fusarium solani is one of the important phytopathogenic causing serious losses on cucurbit plant in Iraq, which is responsible for crown and root rots of melon. All cucurbit crops are susceptible to Fusarium solani in the seedling stage. This pathogenic has two races: race 1 is pathogenic on root, crown and fruit; but race 2 is pathogen only on fruit. Race 1 attacks the hypocotyls, causing a cortical stem rot. It also attacks mature fruit. Race 2 of this pathogenic is reported only in limited areas in the world and has less significance [1]. Fusarium solani f. sp. cucurbitae race 1 and race 2 are not easily distinguished in morphology. We developed a polymerase chain reaction (PCR) assay for rapid identification. PCR methods offer a convenient tool for characterization and analyzing variation of Fusarium solani associated with root and stem rot cucurbit plants. The genetic structure of fungi plays main role in the ability of production of toxins. Genes involved in intermediary and secondary metabolism in fungi are frequently physically linked or cluster. Mycotoxins are defined as low molecular weight fungal secondary metabolites that are toxic to vertebrates [2]. Nanotechnology is the new era of technology which deals with matter at atomic or molecular level. It helps to modify biomarkers, imaging, cell labeling, antimicrobial agents and drug delivery for treatment of diseases [3]. A silver nanoparticle is one of the most thoroughly investigated nonmaterials and owes its popularity to its biocidal properties [4]. Its antimicrobial activity is associated with the characteristic structure of nanoparticles. It exhibits a high antifungal activity [5]. Magnesium oxide nanoparticle is an important inorganic oxide and has been widely used in many fields. Many studies have shown that Magnesium oxide nanoparticles have good antibacterial activity [6]. The present work entitled, "Genetic Diversity of Fusarium solani f. sp. cucurbitae, the Causal Root and Crown Rot of Cucurbits (Melon) by Using Molecular Markers and Control" is an attempt to study some of these aspects with the following objectives.

\section{Objectives}

1) Determine the genetic diversity of Fusarium solani f. sp. cucurbitae by using RAPD marker.

2) Identifying the gene responsible for the production of toxins using specialized primers.

3) Testing the efficiency of some nanomateriales (silver, magnesium oxide) and chemical (phylex) inhibition in fungus destroy or reduced toxin in vitro.

4) Evaluate the efficiency of nanoparticles and chemicals for Suppression fungus under plastic-house condition.

\section{Materials and Methods}

\subsection{Characterization of Magnesium Oxide Nanoparticle}

Magnesium Oxide nanoparticle was prepared from company nanoshild, USA.

Size: $30 \mathrm{~nm}$.

Purity: 99.9\%. 


\subsection{Analysis of Effect of Magnesium Oxide Nano Particles on the Respective Fungus}

Different concentrations of magnesium oxide nanoparticles from PDA media were used for analyzing the antifungal properties. To do so $1 \%, 2 \%$, and $3 \%$ concentrations of magnesium oxide nanoparticles prepared from deionized water. Then mixing each of them individually to the homogenizer for half an hour to ensure mixing well then the expose each one of them to ultrasonic frequency of $22-24 \mathrm{~Hz}$ for two minutes to preserve the nanoscale particle size distribution and to ensure homogeneous distribution in the mixture, add all of the concentration separately to the flask $100 \mathrm{ml}$ container of $2.4 \mathrm{~g}$ (PDA) and $30 \mathrm{ml}$ of distilled water were added to autoclaved growth medium after its temperature reached approximately $40^{\circ} \mathrm{C}-50^{\circ} \mathrm{C}$, agar plugs of uniform size (diameter, $8 \mathrm{~mm}$ ) containing fungi were inoculated simultaneously at the center of each Petri dish containing Magnesium oxides nanoparticles, followed by incubation at $28^{\circ} \mathrm{C} \pm 2^{\circ} \mathrm{C}$ for 14 days. Growth inhibition percent was calculated using the radial growth of mycelium according. The acquired results were compared with those of control group to which no nanoparticles have been added. All tests were conducted in three replications.

\subsection{Characterization of Silver Nanoparticle}

Stock Nan silver solution at concentration $4000 \mathrm{ppm}$ was obtained from company MTI, USA. Different working concentration of silver nanoparticles (50 ppm, 100 ppm, 150 ppm) was prepared by diluting the original stock solution with distilled water [7].

\subsection{Silver Nanoparticles}

In vitro assay was performed on of growth medium (PDA) treated with different concentrations $(50,100,150)$ of silver nanoparticles, The mixing each of them individually to the homogenizer for half an hour to ensure the mixing well then the exposure of the each them to ultrasonic frequency of $22-24 \mathrm{~Hz}$ for two minutes to preserve the nanoscale particle size distribution and to ensure homogeneous distribution in the mixture. Five ml of AgNPs having different concentrations were poured into growth media prior to plating in a Petri dish $(90 \times 15 \mathrm{~mm})$. Media containing silver nanoparticles were incubated at room temperature. After $48 \mathrm{hr}$ of incubation, agar plugs of uniform size (diameter, $8 \mathrm{~mm}$ ) containing fungi were inoculated simultaneously at the center of each Petri dish containing silver nanoparticles, followed by incubation at $28^{\circ} \mathrm{C} \pm 2{ }^{\circ} \mathrm{C}$ for 14 days. Growth inhibition percent was calculated using the radial growth of mycelium according to the following equation.

Growth inhibition $(\%)=\frac{R-r}{R}$, where $R$ is the radial growth of the fungal mycelia on the control plate and $r$ is the radial growth of fungal mycelia on the plate treated with nanoparticles and chemical.

\subsection{Characterization of Phylex}

Dutch selko company experts to affect phylex in preventing fungal growth and myco- 
toxin. It's a mixture of organic acids and their salts if it consists of ascorbic acid, formic acid, lactic acid, citric ammonia, materials publisher and water. It is non-toxic extract.

\subsection{Isolation and Identification of the Pathogen}

Fourth samples from infected plants were taken from root and stem rot naturally diseased cucurbit plant during 2015. These samples were obtained from four provinces (Babylon. Baghdad. Najaf, Diwaniyah). Samples were cut into $0.5-1 \mathrm{~cm}$ and washed under running tap water for 30 minute, then surface sterilized in $1 \%$ sodium hypochlorite for 2 minute and cultured on Potato dextrose agar (PDA) supplemented with 200 mg $\backslash 1$ Tetracycline and incubated at $25^{\circ} \mathrm{C} \pm 1^{\circ} \mathrm{C}$ for 7 days, single spore technique was made for each isolate. Isolates were identified to the species level according to their cultural and morphological characteristic [8].

\subsection{Field Experiment}

Field experiment was conducted at the Diwaniyah a province of Iraq in summer season 2015. Soil used for the experiment was sandy loam containing sand $73 \%$, clay $12 \%$ silt $13 \%, \mathrm{pH}$ 7. Electrical conductivity (E C) $0.63\left(\mathrm{ds} \cdot \mathrm{m}^{-1}\right)$ Seeds of melon were sown in plots $(3 \times 3.5 \mathrm{~m})$ which had 2 rows $(1.5 \mathrm{~m})$. Each row contained 2 hills, spaced $50 \mathrm{~cm}$ apart. Every hill was sown with 4 sterilized seeds and three replicates were used for each treatment.

The effects of Silver nanoparticles (AgNPs), magnesium oxide nanoparticle and phylex were evaluated on melon growth parameters. Pathogen was prepared by growing them on millet grains in $100 \mathrm{ml}$ flask as follow, the grain were soaked overnight in distilled water, autoclaved twice ( $121 \mathrm{c}$ for $45 \mathrm{~min}$. and then inoculated with agar discs of 5 days-old fungal culture. flask were incubated at $28 \mathrm{c}$ in dark for 21 days, the fungal inoculate were then mixed with soil.

Surface sterilization was accomplished by immersing the seeds in $5 \%$ sodium hypochlorite solution for $5 \mathrm{~min}$ and followed by washing by sterile distilled water, all treatment (silver nanoparticles, magnesium oxide nanoparticles, phylex) was accomplished by soaking in with different concentrations for $2 \mathrm{~h}$. There were thirteen groups of treatments with three replications for each treatment. Treatments included: 1 -controll; 2-silver without; 3-silver with pathogen; 4-magnesium oxide nanoparticles without; 5-magnesium oxide nanoparticles with pathogen; 6-Phylex without; 7Phylex with pathogen; 8-nanosilver + magnesium oxide with pathogen; 9-nanosilver + magnesium oxide without pathogen; 10-nanosilver + Phylex with; 11-nanosilver + Phylex without; 12-nanosilver + magnesium oxide + Phylex with pathogen; 13nanosilver + magnesium oxide + Phylex without. The experimental design was complete randomized block with three replicate.

\section{Plant Growth Parameters}

\subsection{Plant Height $(\mathrm{H})$}

The height of the plant was measured from the base of the hypocotyls to the seedling's 
apex. Ruler is used to measure the plant height of each seedling with unit of centimeter $(\mathrm{cm})$.

\subsection{Fresh and Dry Weight of the Plant}

Scale is used to measure fresh and dry weight of the plant: shoot (SFW) and root (RFW) fresh weight plus shoot (SDW) and root (RDW) dry weight. The samples needed to put in oven at $70^{\circ} \mathrm{C} \pm 1^{\circ} \mathrm{C}$ for 72 hours in order to take the dry weight of seedlings.

\subsection{Growth Measures}

The growth measures (plant height, fresh and dry weight of plants and roots) were assessed by using the same methods described in the previous section. The plant and root parameters were recorded separately after 45 days of the experiment, where the plants were uprooted and washed under running tap water.

\subsection{Disease Severities (DS)}

Symptom severity of the areal parts of the plants was assessed $(8,10,12,14$ days after pathogen inoculation) using the following index 0 , no symptoms; 1 , yellowing of the cotyledons or the first leaf; 2, yellowing of two leaves; 3 , yellowing of three or more leaves; 4, died plant. The disease severity index was calculated using the formula [9]. Disease severity index $(\%)=\Sigma=\frac{n i s i}{4 n} \times 1004 N$ where $n i$ is the number of plants affected by each degree of severity, si the degree of severity of the attack $(0-4)$ and $N$ the total number of plants used for each energy level applied.

\subsection{Extract and Purification of DNA}

Grind the tissue in liquid nitrogen with a mortar and pestle [10]. Transfer the tissue into micro centrifuge tube (FAVORGEN. company protocol). Add $1 \mathrm{ml}$ of FA buffer and resuspend the cell by pipette. Descend the cells by centrifuging at $5.000 \times \mathrm{g}$ for min and discard the supernatant completely. Resuspend the cell in $550 \mu \mathrm{l}$ of FB buffer and add $50 \mu \mathrm{l}$ of of lyticase solution, mixed well by vortexing incubate the sample at $37 \mathrm{c}$ for $30 \mathrm{~min}$. Add $8 \mu \mathrm{l}$ of $50 \mathrm{mg} / \mathrm{ml}$ RNase A and incubate for $2 \mathrm{~min}$ at room temperature. Descend the cell by centrifuging of $5000 \mathrm{~g}$ for $10 \mathrm{~min}$. remove the supernatant completely. Add 35o $\mu \mathrm{l}$ TG1 Buffer and mix well by pipetting. Transfer the sample mixture to a bead tube Mix well by plus-vortexing for 5 minute. Add $20 \mu \mathrm{l}$ of proteinase $\mathrm{k}$ (10 $\mathrm{mg} / \mathrm{ml}$ ) and mix well by vortexing. Incubate of $55 \mathrm{c}$ for $15 \mathrm{~min}$, vortex 30 seconds for every 5 minutes incubation.

Descend the cell by centrifuging of $5000 \times \mathrm{g}$ for $1 \mathrm{~min}$ and transfer $20 \mu \mathrm{l}$ of supernatant to a new $1.5 \mathrm{ml}$ micro centrifuge tube. Add $200 \mu \mathrm{l}$ of TG2 Buffer and mix well by pipetting. Add $200 \mu \mathrm{l}$ of ethanol (96\% - 100\%) and mix well by pulse-vortexing for 10 seconds. Place a TG mini column in collection Tube Transfer the sample mixture (including only precipitate carefully to TG mini column. Centrifuge at $11000 \times \mathrm{g}$ for 30 
second and discard the flow through place the TG mini column back to the collection Tube. Add 750 of $\mu \mathrm{l}$ wash Buffer to the TG min column centrifuge of $11000 \times \mathrm{g}$ for 30 seconds and discard the flow through place the TG column back to the collection tube Centrifuge at full speed $(18000 \times \mathrm{g})$ for an additional $3 \mathrm{~min}$ to dry the column. Place the TG mini column to a Elution tube Add 50 - $100 \mu$ of Elution buffer add $\mathrm{H}_{2} \mathrm{O}$ to the membrane center of the TG mini column. Stand TG mini column for 3 min. Centrifuge of full speed $\left(-18000 \times \mathrm{g}\right.$ for $1 \mathrm{~min}$ to elute total DNA. Store total DNA at $4^{\circ} \mathrm{C}$ or $-20^{\circ} \mathrm{C}$.

\subsection{Primer Design}

Primer which has been designed based on 1- $\alpha$ (TEF) gene [11] [12] (Table 1).

RAPD analysis : Amplification reaction were performed in $5 \mu$ master mix (pramago company) $1 \mu \mathrm{l}$ primer forward and $1 \mu \mathrm{l}$ primer reverse, $2 \mu \mathrm{l}$ Genomic DNA and $1 \mu \mathrm{l}$ distilled water in a final volume of $10 \mu \mathrm{l}$ (Table 2).

Reaction conditions were $94 \mathrm{c}$ for $10 \mathrm{~min}$ followed by 35 cycles of $94 \mathrm{c}$ for $1 \mathrm{~min}, 56 \mathrm{c}$ for $1 \mathrm{~min}$ and $72 \mathrm{c}$ for $1 \mathrm{~min}$. The final extension was at $72 \mathrm{c}$ for $10 \mathrm{~min}$. PCR Products were loaded on a $1.5 \%$ agarose gel with $0.1 \%$ ethidium bromide in Tri-acetate EDTA buffer, separated for $30 \mathrm{~min}$ at $100 \mathrm{v}$, and visualized under ultraviolet light. Cotoxigenicity was determined with the polymerase chain reaction (PCR) using master mix $5 \mu \mathrm{l}$ forward primer $1 \mu \mathrm{l}$ and $1 \mu \mathrm{l}$ Reverse DNA $2 \mu \mathrm{l}$ and 1distilled water to final volume 10 $\mu$ l.

The reaction was performed which involved 30 cycles PCR 94 c 2 min and $94 \mathrm{c} 1 \mathrm{~min}$ 72 c 2 min and 725 min (Table 3, Table 4).

The molecular size of each fragment was estimated using a standard curve of migration versus the $\log$ of the molecular size of 100 bp ladder. Each fragment was scored on

Table 1. (a) Primers used in PCR assay; (b) Primers used in PCR assays.

(a)

\begin{tabular}{cccc}
\hline No. & Test & Sequence (5'-3') & Source \\
\hline 1 & F. solani f. sp. cucurbitaef & 5'-GCTAACAATCAT CTACAGAC-3 & Mehl and L. Epstein \\
2 & R & 5'-GACGGA TGAGAGAGCAAC-3') & \\
3 & F & CGTGATTGGGACGGATGAGAGA & (Hong et al. 2010) \\
4 & R & TGGCATCTTGGGCGGGGGGT & \\
\hline
\end{tabular}

(b)

\begin{tabular}{cccc}
\hline No. & Test & Sequence (5'-3') & Source \\
\hline 1- & $\begin{array}{c}\text { F. solani f. sp. } \\
\text { cucurbitae }\end{array}$ & $\begin{array}{r}\text { 5'-GCTAACAATCAT CTACAGAC-3 } \\
\text { (5'-GACGGA TGAGAGAGCAAC-3') }\end{array}$ & Mehl and L. Epstein \\
2- & Tri 5 $\mathrm{f}$ & 5'-GATTGAGCAGTACAACTTTGG-3' & \\
& Tri5 R & 5'-ACCATCCAGTTCTCCATCTG-3' & \\
3- & Tri13 F & TACGTGAAACATTGTTGGC & Waalwijk et al. (2003) \\
& Tri13 R & GGTGTCCCAGGATCTGCG & \\
\hline
\end{tabular}


Table 2. PCR reaction.

\begin{tabular}{ccc}
\hline No. & Substance & Volume per reaction $(\mu \mathrm{l})$ \\
\hline 1 & Master mix & 5 \\
2 & Free water & 1 \\
3 & Forward primer & 1 \\
4 & Reverse primer & 1 \\
5 & DNA & 2 \\
6 & Reaction volume & $10 \mu \mathrm{l}$ \\
\hline
\end{tabular}

Table 3. Parameters of thermal profile.

\begin{tabular}{ccc}
\hline PCR cycles steps & Temperature $\left[{ }^{\circ} \mathrm{C}\right]$ & Time $(\mathrm{min})$. \\
\hline Initial denaturation & 94 & 2 \\
Denaturation & 94 & 1 \\
Annealing & Table & 1 \\
Elongation & 72 & 2 \\
Final extension & 72 & 5 \\
Cooling & 4 & - \\
\hline
\end{tabular}

Table 4. Annealing conditions in particular PCR assays Date analysis.

\begin{tabular}{cc}
\hline Test & Temperature $\left[{ }^{\circ} \mathrm{C}\right]$ \\
\hline F. solanif. sp. cucurbitae & 56 \\
Tri5 & 58 \\
Tri 13 & 60 \\
\hline
\end{tabular}

the basis of the presence (1) or absence (0) of particular fragments. A date matrix was constructed based on the presence or absence of the fragments and converted to a similarity matrix.

\section{Results}

\subsection{Growth of the Fungal Colony}

The results showed that Fusarium solani was predominant in all simple with $100 \%$ frequency. Fusarium solani forms white to cream color mycelium on the PDA. Microscopic examination was showed three types of spores, macroconidia were spindle to cylindrical shape containing between three to five septa with distinctly or barely notched basal cells, microconidia formed on false head on long monophialides, growth laterilly on the aerial mycelium. Chlamydospores terminal and intercalars single or in chains Figure 1(a) and Figure 1(b). 


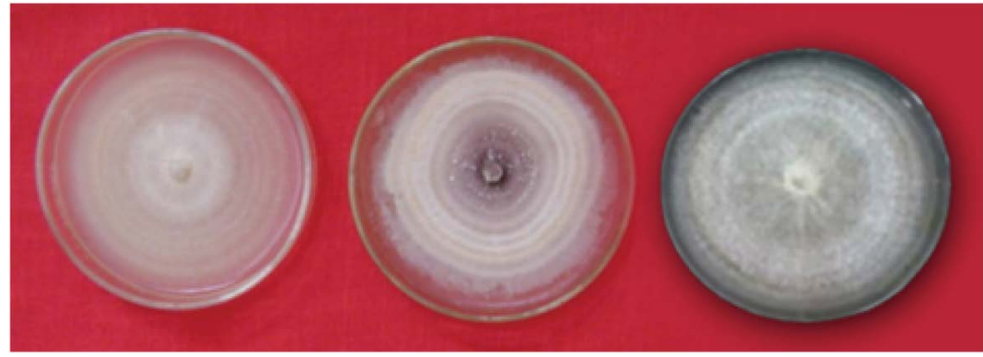

(a)

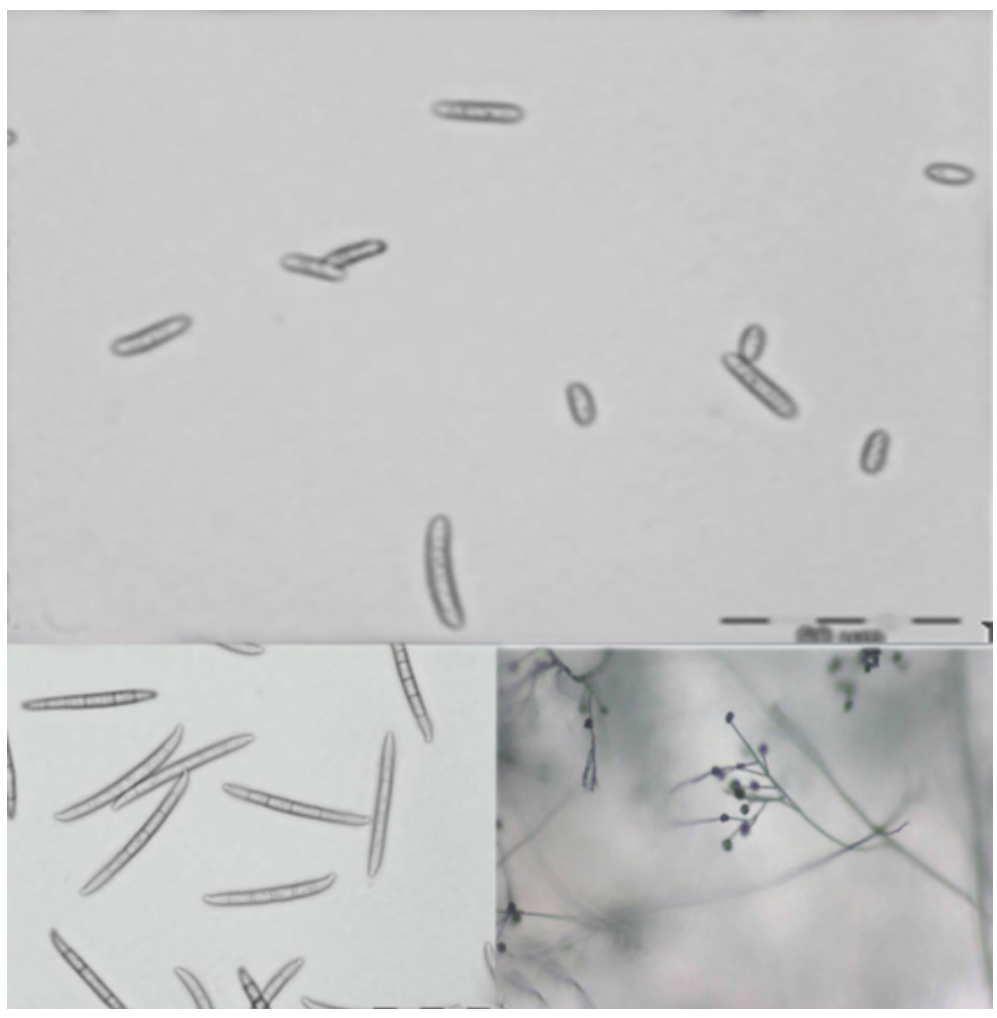

(b)

Figure 1. Cultural characteristics of $F$. solani the causal agent of the crown and root rot disease of melon. (a) Growth of the fungal colony on the PDA; (b) Microscopic characteristics of F. solani the causal agent of the crown and root rot disease of melon on carnation leaf-piece agar medium (1) Micro conidia; (2) Macro conidia; (3) Long monophialides conidiospher.

\subsection{Pathogenicity Test}

All isolates of the Fusarium solani were tested for their pathogenicity on apparently healthy and uniform 7 days old seedling melon in the greenhouse. Roots and stems of the melon seedling were washed in running tap water before inoculation. Conidial suspension of each individual isolate was prepared by pouring sterile distilled water and gently scraping the conidia of 7 days old cultures on PDA plates grown under the standard grown condition. The concentration of the pooled suspension was adjusted to $2 \times$ $10^{6}$ conidia/ml by using ahaemocytometer.

The roots of seedling were soaking in $20 \mathrm{ml}$ conidial suspension for $20 \mathrm{~min}$ for root 
inoculation technique for stem inoculation technique, $20 \mathrm{ml}$ of the conidial suspension of each Fusarium solani was sprayed on the stems. The control plants were inoculated by booth techniques with $\mathrm{ml}$ of sterile distilled water. Three replicates were performed for each isolate and the experiment was repeated twice. Results of the pathogenicity test showed that all isolates of Fusarium solani were highly pathogenic to melon plants. The first wilting occurred 7 days after inoculation in melon plants. 100 percentage of melon plants inoculated with the forty isolates died, inoculated plants exhibited a cortical rot at the base of the stem and upper part of the root system caused discoloration and necrosis then brown rot of the stems. While all uninoculated plants remained asymptomatic, the pathogen was recovered from symptomatic plants, fulfilling Koch s postulates.

\subsection{In Vitro Antifungal Assays}

Results presented in this study confirm that nanoparticles have significant inhibitory effects and antifungal activity on colony formation from mycelia of Fusarium solani in vitro. The growth rate of strain in the presence of the tested nanoparticles and other compound chemical are summarized in Table 5.

There were significant differences between different concentrations of nanoparticles on growth inhibition of Fusarium solani, while there was no growth inhibition in the negative control. The higher inhibition of fungal growth was recorded at a concentration of $150 \% \mathrm{ppm}$ from silver nanoparticle was observed on PDA medium. Concentration of $100 \%, 50 \%$ ppm inhibition of the fungal growth is by $98 \%$ and $88.9 \%$ respectively.

The different concentration of $\mathrm{MgO}$ nanoparticles caused inhibition the fungal growth, higher inhibition at $3 \%, 2 \%$ by $100 \%$ meanwhile at concentration of $1 \%$ by 92.1\% (Figure 2).

Table 5. The growth rate of strain.

\begin{tabular}{ccccc}
\hline No. & Treatment & Concentration & Growth fungi & Growth inhibition \% \\
\hline 1 & Silver nanoparticle without & & 9.0 & - \\
2 & AgNPs & $50 \%$ & 1.0 & 88.9 \\
3 & AgNPs & $100 \%$ & 0.18 & 98 \\
4 & AgNPs & $150 \%$ & 0.0 & 100 \\
5 & MgoNPs & $1 \%$ & 0.719 & 92.1 \\
6 & MgoNPs & $2 \%$ & 0.0 & 100 \\
7 & MgoNPs & $3 \%$ & 0.0 & 100 \\
8 & MgoNPs without & & 9.0 & - \\
9 & Phylex & & 1.7 & 81.1 \\
10 & Phylex & 0.1 & 0.75 & 91.66 \\
11 & Phylex & 0.2 & 0.0 & 100 \\
12 & Phylex without & 0.3 & 9.0 & - \\
\hline
\end{tabular}


The higher inhibition of fungal growth was recorded at a concentration of 0.3 from Phylex by $100 \%$ and, $91.66 \%, 81.1 \%$ with a concentration $0.2,0.1$ (Figure 3 ).

The results in the current study are confirmed by the finding of [3], which reported that the synthesized nanoparticles can significantly inhibit (87.1\%, 86.5\% and $83.5 \%)$ to growth of phytopathogens Colletotricum coccodes (Figure 4).

[13] reported that the controlling effect increases in the administered dosage of nanoparticle and there exists a direct correlation between the administered dosage and controlling effect, the concentration of $2 \%$ MgoNps had the greatest effect in both liquid and solid media, [14] reported that the when roots were drenched with MgoNps suspension prior to inoculation with pathogen, the incidence of disease was significantly reduced. Also, these results agree with selko Dutch company research regarding

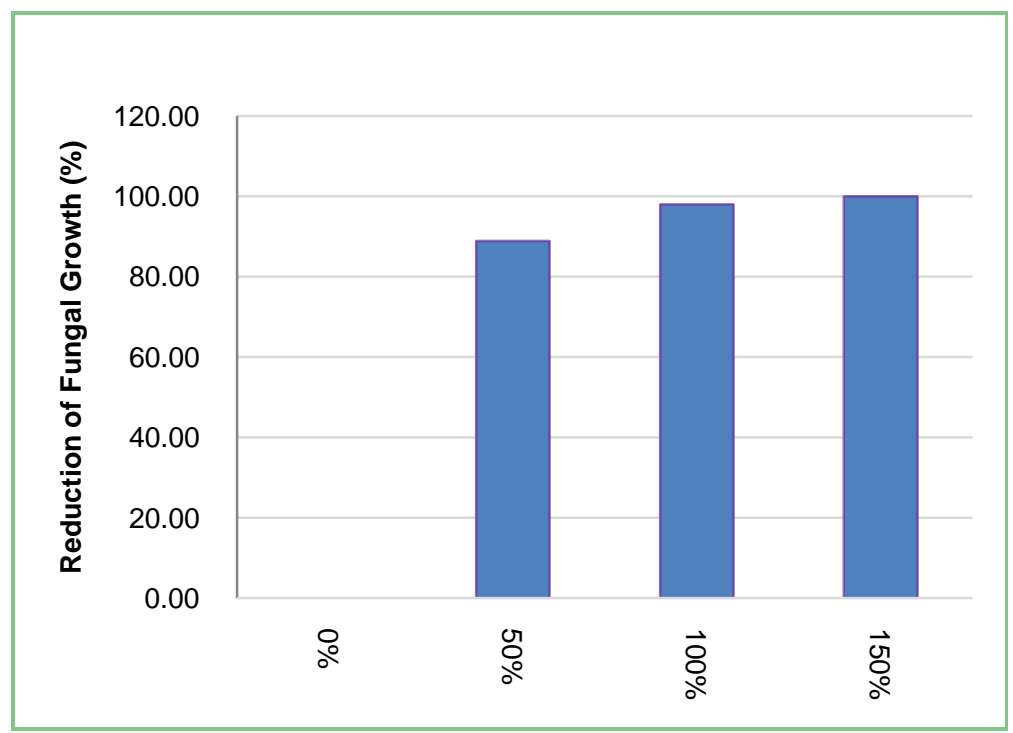

Figure 2. AgNps concentration (ppm).

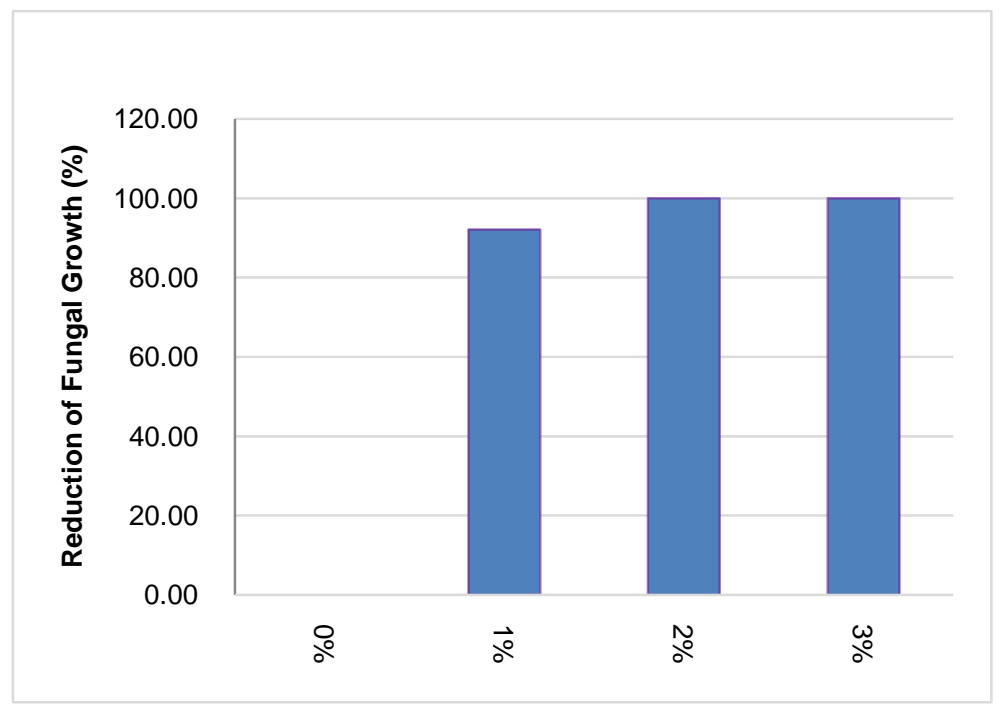

Figure 3. MgoNps concentration (ppm). 


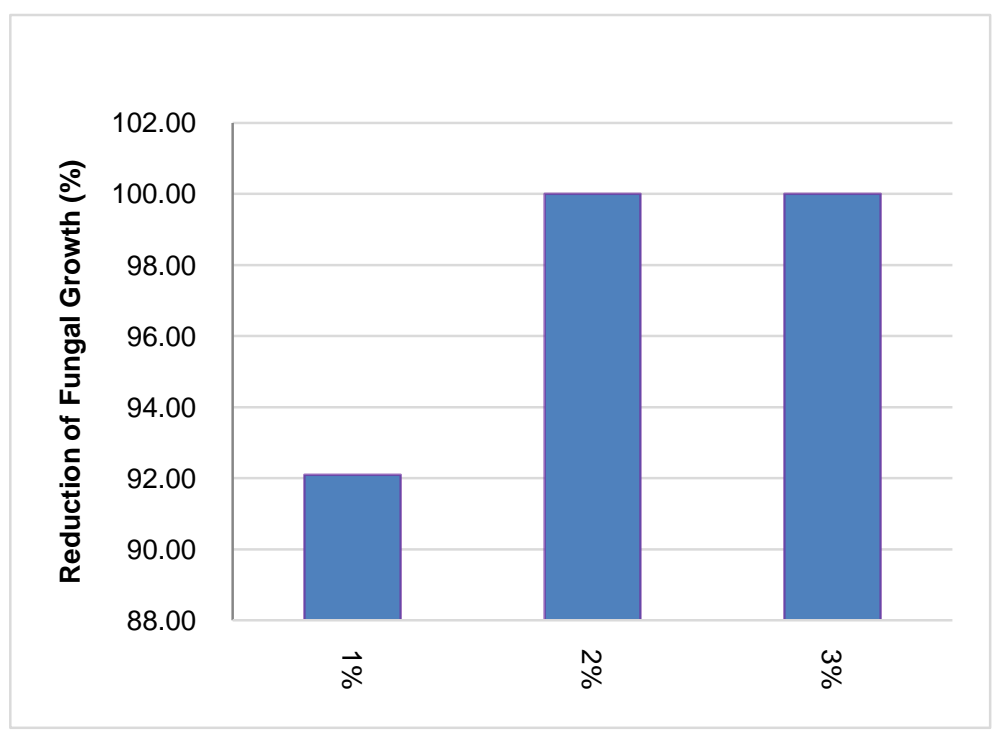

Figure 4. Phylex concentration.

item phylex inhibitory immune substance for the growth of many fungi. The results are close conformity with finding of [5]. It reported that the inhibitory effected of nanoparticle may be due to the directly attach to and penetrate the cell membrane of the spore and killed them. Also [7] reported that antimicrobial activity of AgNps on microorganism was depended on the concentration of AgNps and was closely associated with the formation of pits in the cell wall of the microorganism than Ag accumulated in the membrane caused the permeability, resulting in the cell death. Inhibition increased at the concentration of AgNps increased. This could be due to high density at which the solution was able to saturate and cohere to fungal hypha and deactivate plant pathogenic fungi.

\subsection{In Field Experiment}

\subsubsection{Plant Height}

In the field experiment, data show that the highest shoots were obtained for the plant grown in T13 $(95 \mathrm{~cm}), \mathrm{T} 10(86 \mathrm{~cm})$ followed by $12(75 \mathrm{~cm}), \mathrm{T} 11(70 \mathrm{~cm})$. The lowest plant height was given for those plant grown in T1 $(33 \mathrm{~cm}), \mathrm{T} 5(37 \mathrm{~cm}), \mathrm{T} 3(44.6 \mathrm{~cm})$. No significant difference of plant height was observed between T3, T5. Theses result agreement with [15]. Who reported that nanoparticles penetrate easily inside the plant cell wall and cause effect on biomass and growth parameters' of mung bean plant (Figure 5).

\subsubsection{Fresh and Dry Shoot Weight}

The results showed that the effect of different type of nanoparticles was significant on fresh and dry shoot The highest fresh shoot and dry weight were obtained for the plant grown in T13 (6.403 g), (1.206 g). The lowest shoot and dry weight was given for these plant grown in T1, T3, T5. No significant difference of shoot and dry weight were observed between $\mathrm{T} 3, \mathrm{~T} 5$. The data obtained are in agreement with the previously published 


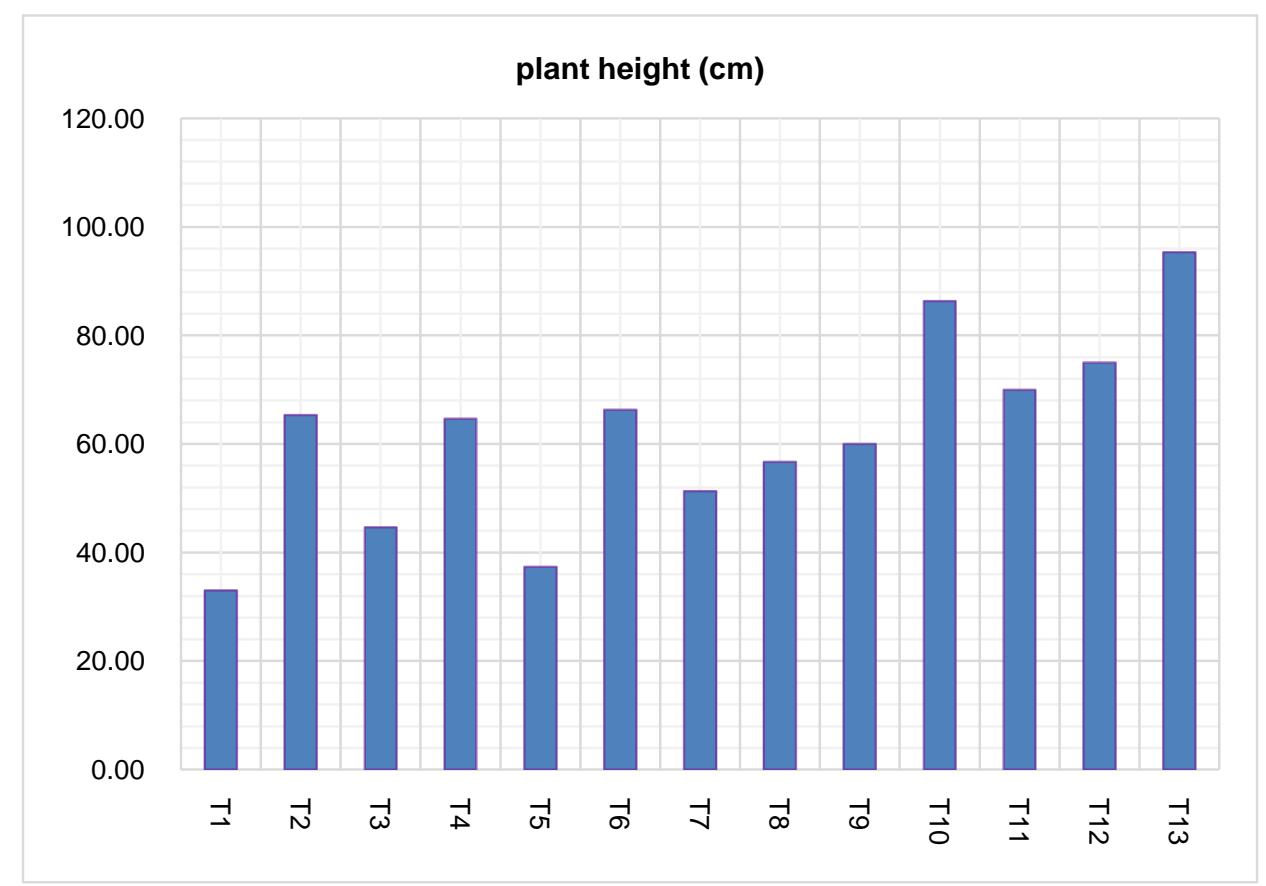

Figure 5. Plant height of melon treated with thirteen treatments.

results by [5]. Reported that all level of silver nanoparticles (25, 50, 100, $150 \mathrm{ppm})$ applied to soil in pots significantly enhanced fresh weight, dry weight and chlorophyll content over control (Figure 6 and Figure 7).

\subsubsection{Fresh and Dry Root Weight}

Results showed that fresh and dry weight of melon seedling root significantly. According to root fresh weight, treatment were grouped with significant differences in groups, T13, T11 had the highest weight $(2.65 \mathrm{~g}),(1.09 \mathrm{~g})$. Positive control T1 and T3 had lowest weight. Root dry weight, treatment T13, T11 had highest weight $(0.365 \mathrm{~g}),(0.2255$ g), while treatment T1, T3, T5 had lowest weight (Figure 8 and Figure 9).

These results support the finding of [16], who reported that the application of silver nanoparticle significantly enhanced seed germination potential, improved percent seed germination, germination time seed vigor index seedling fresh weight and dry weight it was found that the accumulation and uptake of nanoparticle was dependent on the exposure concentration.

\subsection{Molecular Characteristics of the Pathogen Fungi}

\subsubsection{Molecular Analysis}

A PCR product from isolates of the $F$. solani f. sp. race 1 was amplified by using primer pairs (Fsc1-Efl) produced $580 \mathrm{bp}$ fragment to thirty-two Isolates from forty isolates different provinces of IRAQ (Figures 10-18, Table 6).

The Results showed presences of eight isolates no interaction with primers race 1, despite of morphology identification showed these isolates belong F. solani based on taxonomic key [17]. 


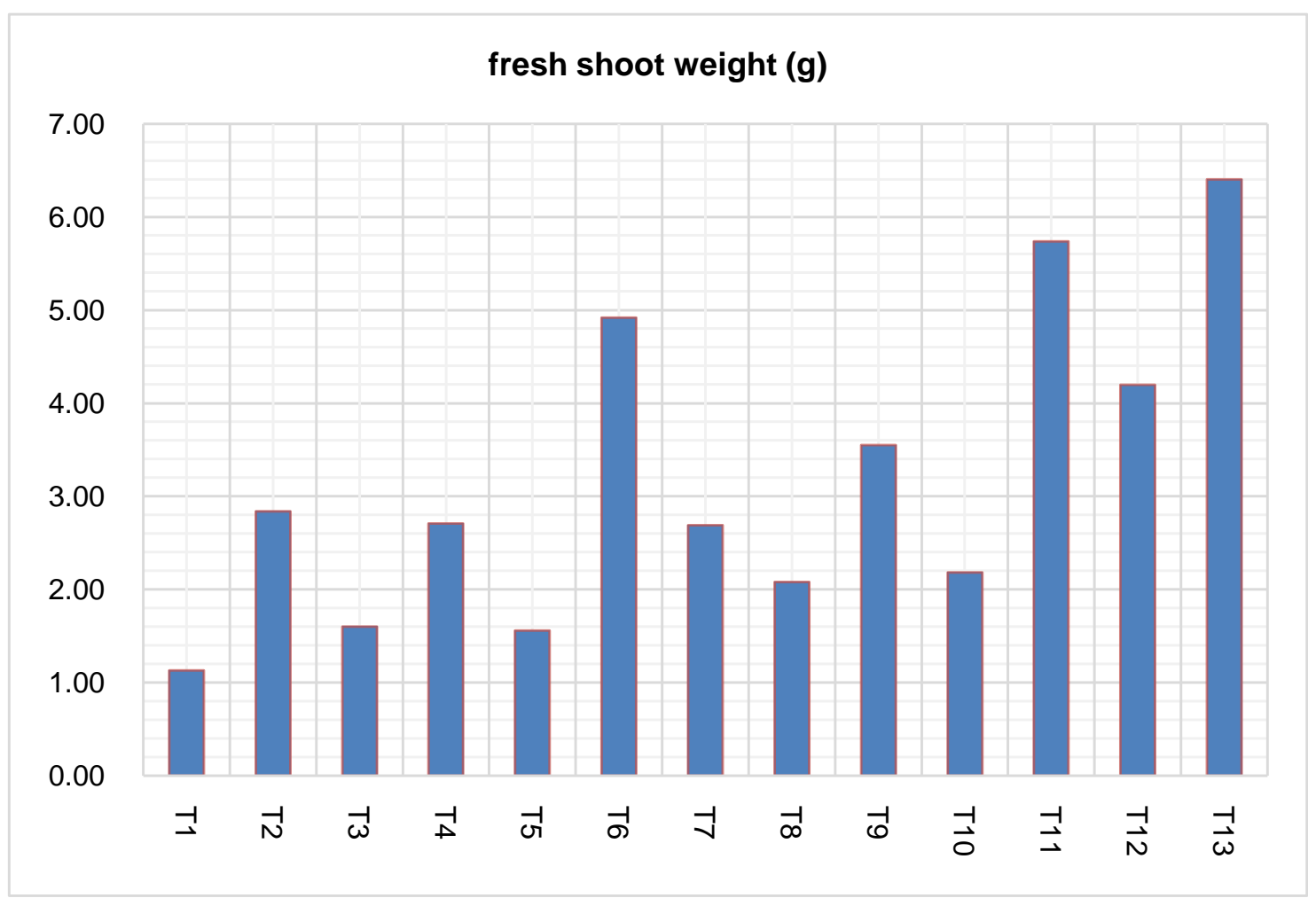

Figure 6. Fresh shoot weight of melon seedling treated with different treatment.

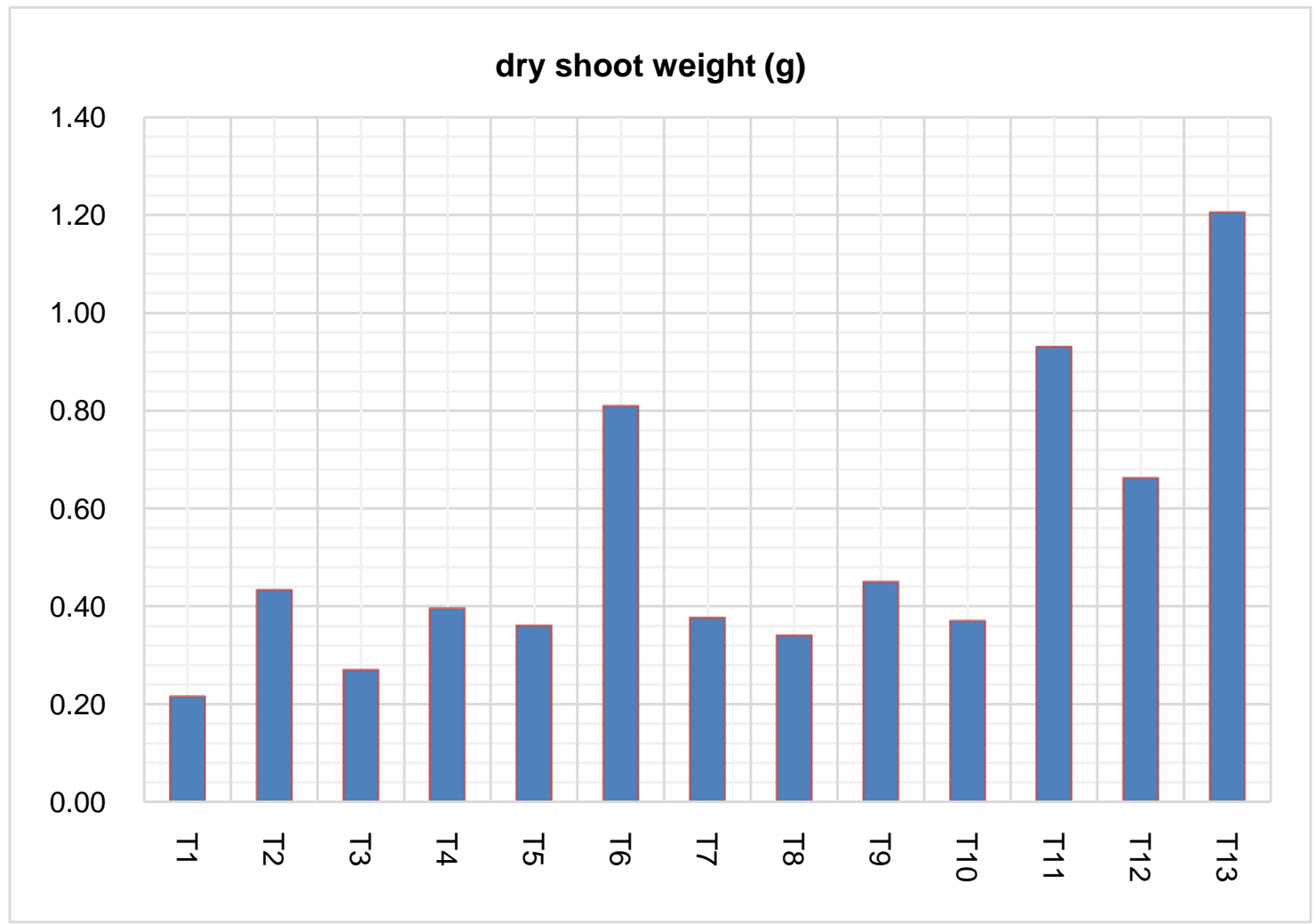

Figure 7. Shoot dry weight of melon treated with different treatment. 


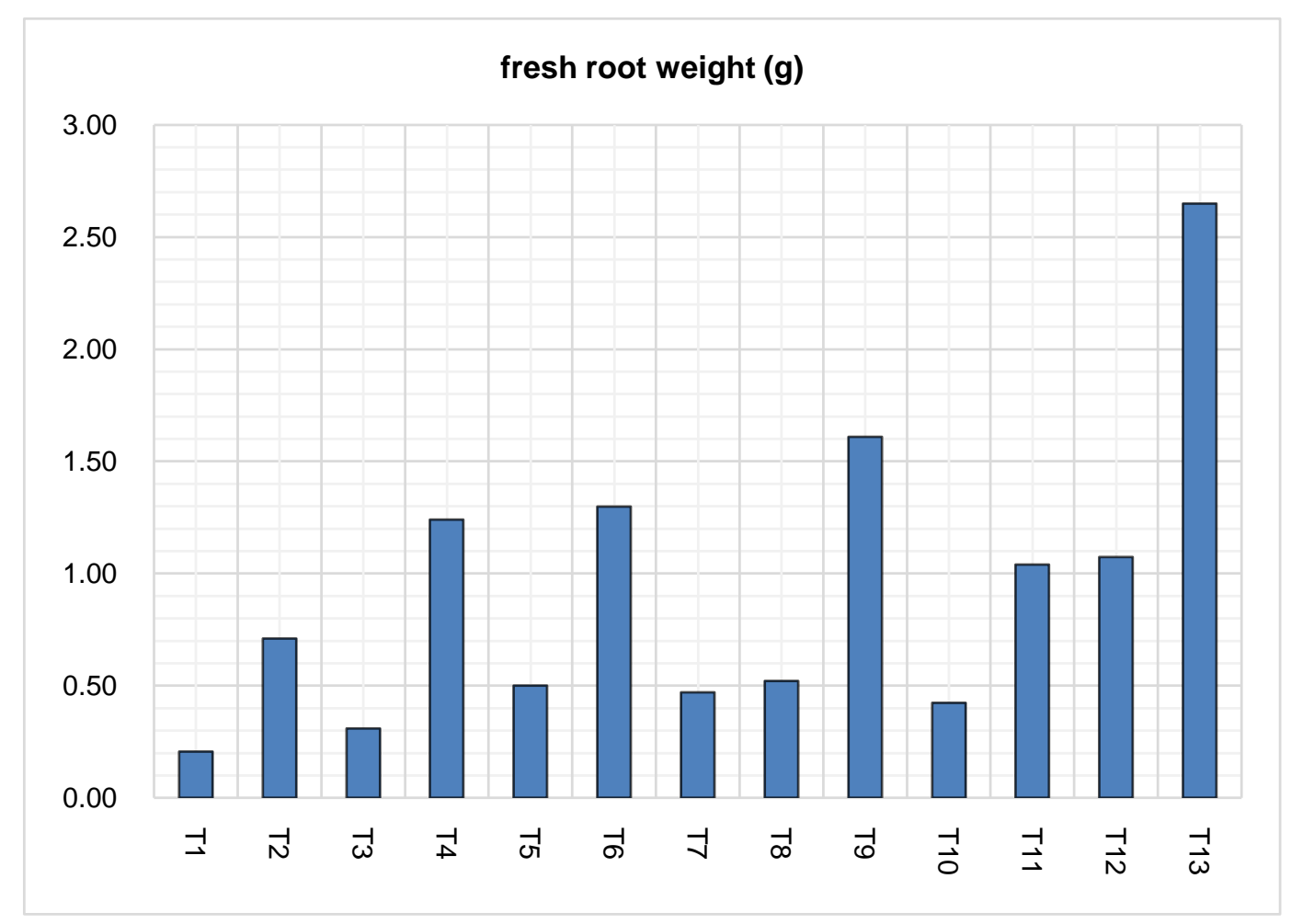

Figure 8. Fresh and dry root weight.

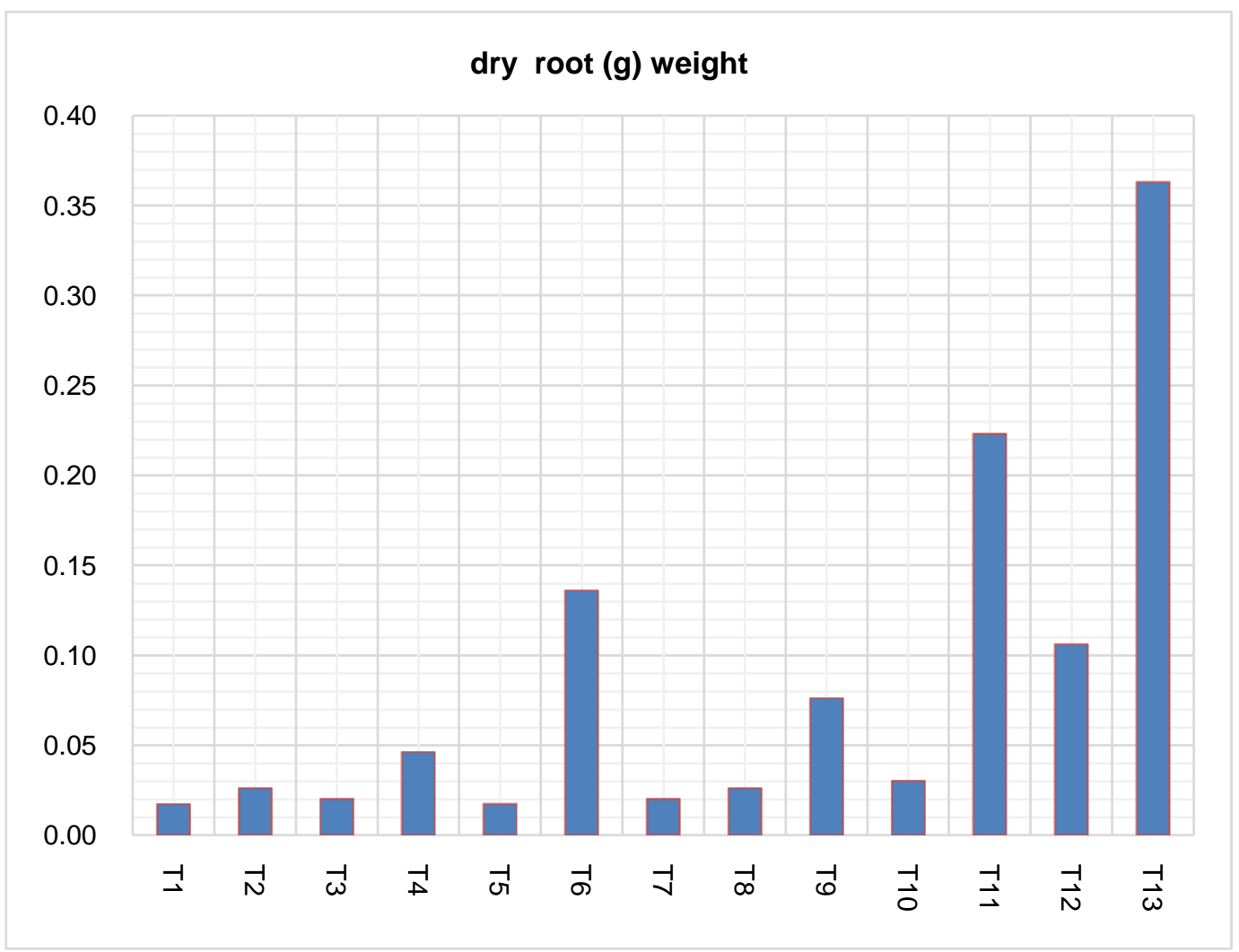

Figure 9. Dry root weight. 
Table 6. Thirty-two isolates of Fsc amplified positively with primer of race 1 (Fsc-EFl).

\begin{tabular}{|c|c|c|c|c|}
\hline No. & Code & Simple set & Primer1 & Primer 2 \\
\hline 1 & B1 Fs3 & Babylon & + & - \\
\hline 2 & B1Fs2 & Babylon & + & - \\
\hline 3 & B1Fs1 & Babylon & + & - \\
\hline 4 & B2Fs6 & Babylon & + & - \\
\hline 5 & B2Fs5 & Babylon & + & - \\
\hline 6 & $\mathrm{~B} 2 \mathrm{Fs} 4$ & Babylon & - & - \\
\hline 7 & B3Fs9 & Babylon & + & - \\
\hline 8 & B3Fs7 & Babylon & + & - \\
\hline 9 & B3Fs8 & Babylon & + & - \\
\hline 10 & D4Fs10 & Diwaniyah & - & - \\
\hline 11 & D4Fs12 & Diwaniyah & + & - \\
\hline 12 & $\mathrm{D} 4 \mathrm{fs} 11$ & Diwaniyah & + & - \\
\hline 13 & D5Fs13 & Diwaniyah & + & - \\
\hline 14 & D5Fs14 & Diwaniyah & + & - \\
\hline 15 & D5fs 15 & Diwaniyah & + & - \\
\hline 16 & D6Fs16 & Diwaniyah & + & - \\
\hline 17 & D6Fs18 & Diwaniyah & + & - \\
\hline 18 & D6Fs17 & Diwaniyah & + & - \\
\hline 19 & BG7Fs19 & Baghdad & + & - \\
\hline 20 & BG7Fs20 & Baghdad & + & - \\
\hline 21 & BG7Fs21 & Baghdad & - & - \\
\hline 22 & BG8Fs24 & Baghdad & - & - \\
\hline 23 & BG8Fs22 & Baghdad & + & - \\
\hline 24 & BG8Fs23 & Baghdad & + & - \\
\hline 25 & BG9Fs25 & Baghdad & + & - \\
\hline 26 & BG9Fs27 & Baghdad & + & - \\
\hline 27 & BG9Fs26 & Baghdad & + & - \\
\hline 28 & N10Fs29 & Najaf & + & - \\
\hline 29 & N10Fs28 & Najaf & + & - \\
\hline 30 & N 10Fs30 & Najaf & + & - \\
\hline 31 & N11Fs32 & Najaf & + & - \\
\hline 32 & N11Fs31 & Najaf & + & - \\
\hline 33 & N11Fs33 & Najaf & + & - \\
\hline 34 & $\mathrm{~N} 12 \mathrm{Fs} 36$ & Najaf & + & - \\
\hline 35 & N12Fs34 & Najaf & + & - \\
\hline 36 & N12Fs35 & Najaf & + & - \\
\hline 37 & M13Fs39 & Ministry of science & + & - \\
\hline 38 & K14Fs39 & College of Agriculture Kufa & + & - \\
\hline 39 & K15Fs37 & College of Agriculture Kufa & + & - \\
\hline 40 & C16Fs40 & Collage of science & + & - \\
\hline
\end{tabular}




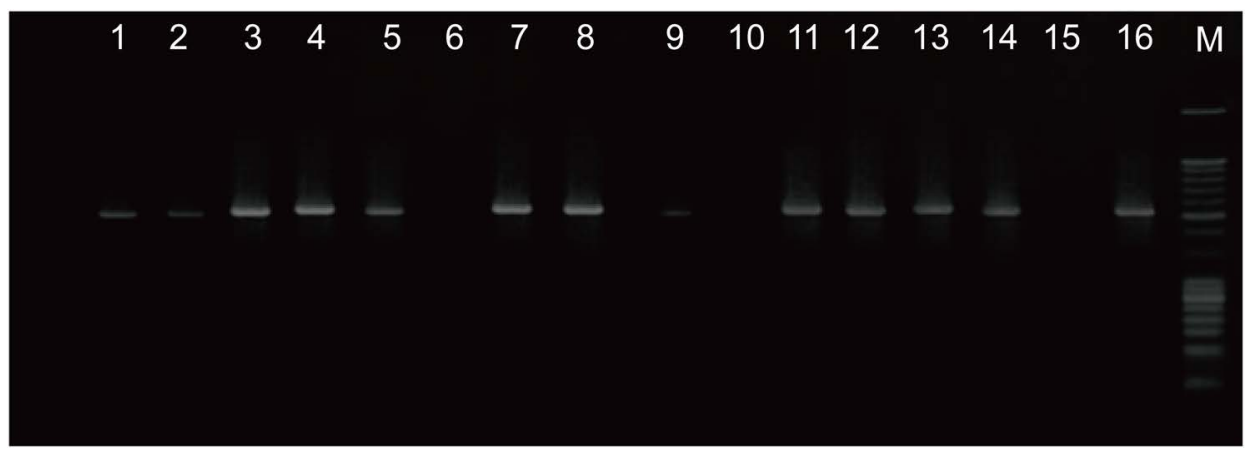

Figure 10. Agarose gels showing; PCR products of $F$. solani f. sp. cucurbite race 1 DNA samples tested using the primer pairs (Fsc1-EFI). A (1 - 9 Babylon isolates), (10 - 18 Diyowinia isolates).

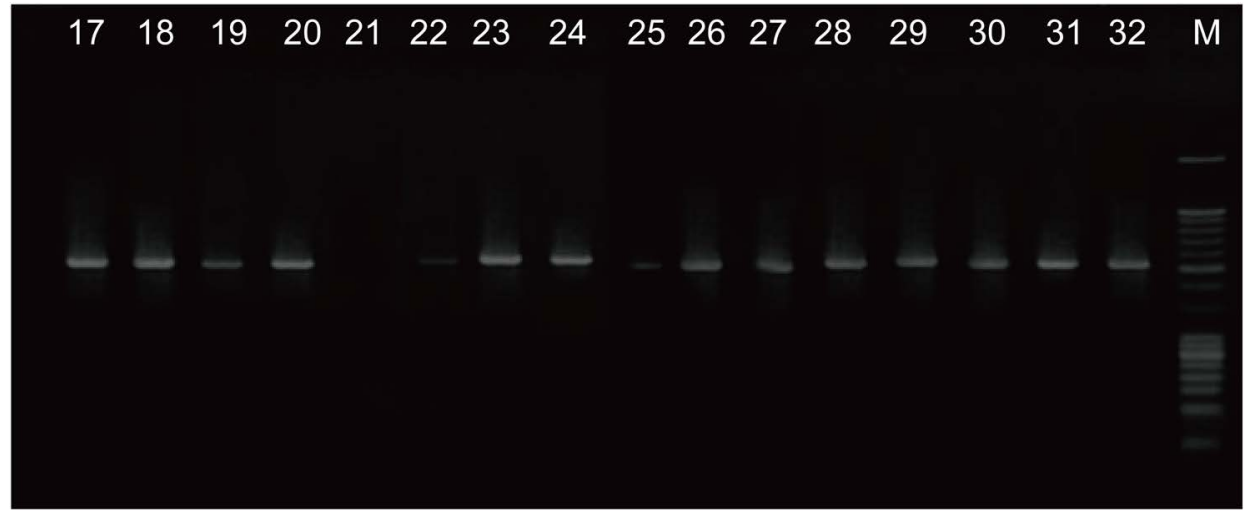

Figure 11. PCR products of $F$. solani f. sp. cucurbite race 1. Agarose gel showing: DNA samples tested using the primer pairs (Fsc-EF1), (19 - 27 Baghdad isolates), (28 - 36 Najaf isolates).

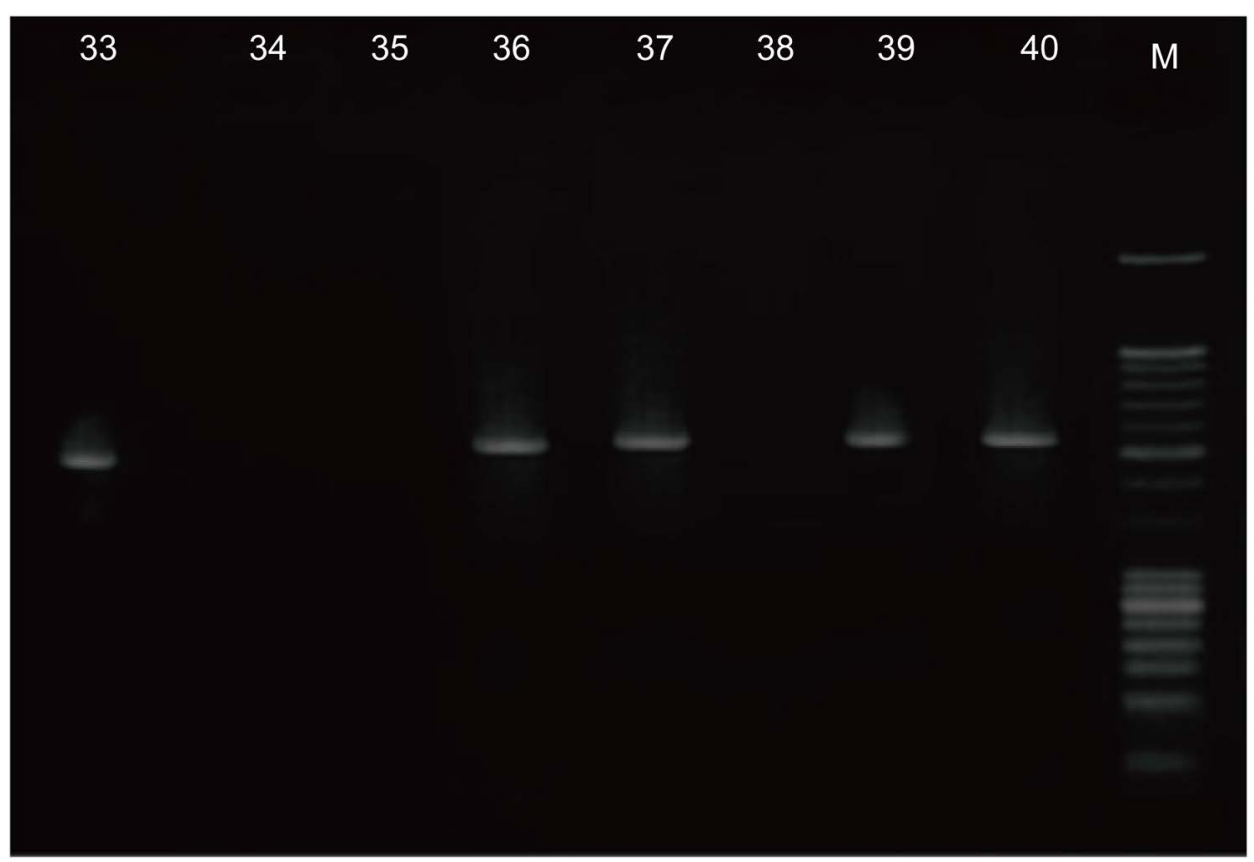

Figure 12. Agarose gel showing PCR products of $F$. solani f. sp. cucurbite race 1 DNA samples tested using the primer pairs (Fsc-EFI), (36 - 40). 
The results of this study are in agreement with those of previous literatures [18] who the first molecular identification of Fusarium solani f. sp. cucurbite racel and race 2 by using PCR assay [19] reported that the primer pair Fsc1 amplified 580 bp fragments from genome DNA of the three race 1 isolates Fsolani f. sp. cucurbitae none of the race 2 isolates including generated the specific amplified fragment

\subsubsection{Molecular Analysis}

The molecular analysis of the potential capacity for producing T2 toxin, Deoxynivalenol by Fusarium solani isolated from root and crown rot of melon. Thirty-nine isolates of Fusarium solani amplified positively with specific primer Tri5 (T2 toxin), while thirty-seven isolates amplified positively with specific primer Tri13 (DON toxin) (Table 7).

The product size of T2 (260 pb) were amplified in PCR reaction (Figures 13-15).

The results in the current study are confirmed by the findings of [19]. Who reported that the Fusarium solani had the strongest ability to produce T-2 toxin in both susceptible and resistant cultivars.

\subsubsection{Tri 13 Gene}

The results showed that the product of amplification of Tri13 gene, $(282 \mathrm{pb})$, with thirty-seven isolated in PCR reaction, while non of three isolates was capable for the synthesis of Deoxynivalenol (Figures 16-18).

\section{Conclusions}

Morphological characteristics of Fusarium solani were isolated from root and stem rot naturally diseased cucurbit plants grown in Iraq, based on the morphological characteristics. The results obtained in this study indicated that $F$. solani was one of the most frequently isolated species. Also, Fusarium solani pathogens are over the roots with negative seedling growth and positive with the occurrence of root diseases.

In present study, RAPD-PCR was carried out to determine the degree of genetic variability within pathogenic isolates of $F$. solani, obtained from root and stem rot diseased cucurbit plants grown in Iraq. Results demonstrated that those taxonomical studies using molecular method and Fusarium solani strains were in agreement with previous molecular and morphological classification criteria. Secondary metabolite production in filamentous fungi is orchestrated by the co-regulation of biosynthetic genes frequently arranged in clusters. Tri5 is the central gene of a $25 \mathrm{~kb}$ gene cluster containing 12 co-regulated genes of which 10 genes are essential for Trichothecene biosynthesis. F. solan isolates included gene Tri5 and thus they were potentially capable of producing trichothecenes. PCR assay is based on the Tril3 gene to identify the genetic potential of DON of F. solani. In this study, only thirty-seven Fusarium solani were found to be potentially deoxynivalenol-producing strains, as they gave positive amplification of $282 \mathrm{bp}$ product with Tri13. Nanoparticles interact with plants causing many morphological and physiological changes, depending on the properties of NPs. Efficacy of NPs is determined by their chemical composition, size, surface covering, reactivity, and most importantly the dose at which they are effective. NPs increased plants growth 
Table 7. PCR assay results of Fusarium solani strains examined in this study.

\begin{tabular}{|c|c|c|c|c|}
\hline No. & Code & Samples set & Tri5 & Tri13 \\
\hline 1 & B1 Fs3 & Babylon & + & + \\
\hline 2 & B1Fs2 & Babylon & + & + \\
\hline 3 & $\mathrm{~B} 1 \mathrm{Fs} 1$ & Babylon & + & + \\
\hline 4 & B2Fs6 & Babylon & + & + \\
\hline 5 & B2Fs5 & Babylon & + & + \\
\hline 6 & $\mathrm{~B} 2 \mathrm{Fs} 4$ & Babylon & + & + \\
\hline 7 & $\mathrm{~B} 3 \mathrm{Fs} 9$ & Babylon & + & + \\
\hline 8 & B3Fs7 & Babylon & + & + \\
\hline 9 & B3Fs8 & Babylon & + & + \\
\hline 10 & D4Fs10 & Diwaniyah & + & + \\
\hline 11 & D4Fs12 & Diwaniyah & + & + \\
\hline 12 & D4fs11 & Diwaniyah & + & + \\
\hline 13 & D5Fs13 & Diwaniyah & + & + \\
\hline 14 & D5Fs14 & Diwaniyah & + & + \\
\hline 15 & D5fs15 & Diwaniyah & + & + \\
\hline 16 & D6Fs16 & Diwaniyah & + & + \\
\hline 17 & D6Fs18 & Diwaniyah & + & + \\
\hline 18 & D6Fs17 & Diwaniyah & + & + \\
\hline 19 & BG7Fs19 & Baghdad & + & - \\
\hline 20 & BG7Fs20 & Baghdad & + & + \\
\hline 21 & BG7Fs21 & Baghdad & + & + \\
\hline 22 & BG8Fs24 & Baghdad & + & + \\
\hline 23 & BG8Fs22 & Baghdad & + & + \\
\hline 24 & BG8Fs23 & Baghdad & + & + \\
\hline 25 & BG9Fs25 & Baghdad & + & + \\
\hline 26 & BG9Fs27 & Baghdad & + & + \\
\hline 27 & BG9Fs26 & Baghdad & + & + \\
\hline 28 & N10Fs29 & Najaf & + & + \\
\hline 29 & N10Fs28 & Najaf & + & - \\
\hline 30 & N 10Fs30 & Najaf & + & + \\
\hline 31 & N11Fs32 & Najaf & + & + \\
\hline 32 & N11Fs31 & Najaf & + & + \\
\hline 33 & N11Fs33 & Najaf & + & + \\
\hline 34 & N12Fs36 & Najaf & + & + \\
\hline 35 & N12Fs34 & Najaf & + & + \\
\hline 36 & N12Fs35 & Najaf & - & - \\
\hline 37 & M13Fs39 & Ministry of science & + & + \\
\hline 38 & K14Fs39 & College of Agriculture Kufa & + & + \\
\hline 39 & K15Fs37 & College of Agriculture Kufa & + & + \\
\hline 40 & C16Fs40 & College of science Babylon & + & + \\
\hline
\end{tabular}




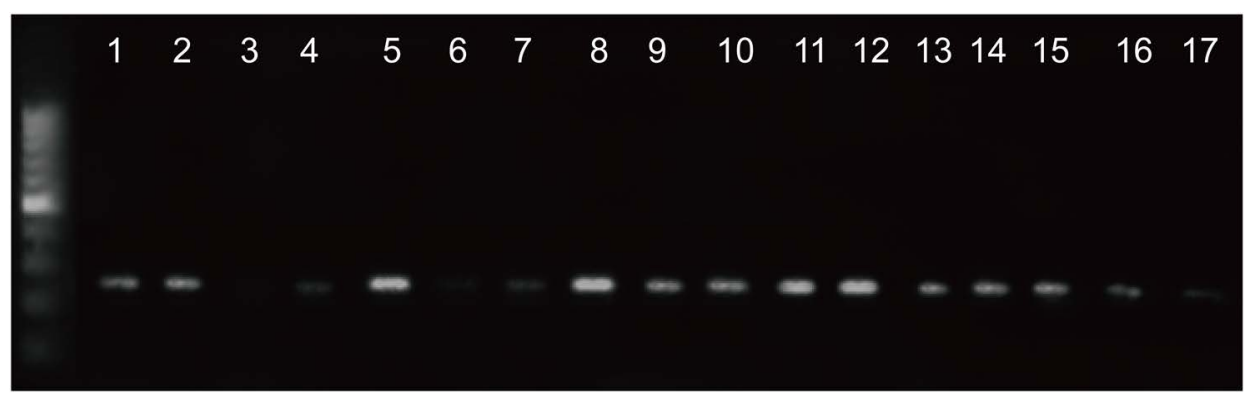

Figure 13. Molecular analysis of potential capacity for producing F. solani mycotoxin.

$\begin{array}{lllllllllllllllll}18 & 19 & 20 & 21 & 22 & 23 & 24 & 25 & 26 & 27 & 28 & 29 & 30 & 31 & 32 & 33 & 34\end{array}$

Figure 14. Molecular analysis of potential capacity for producing T2 toxin by Fusarium solani.

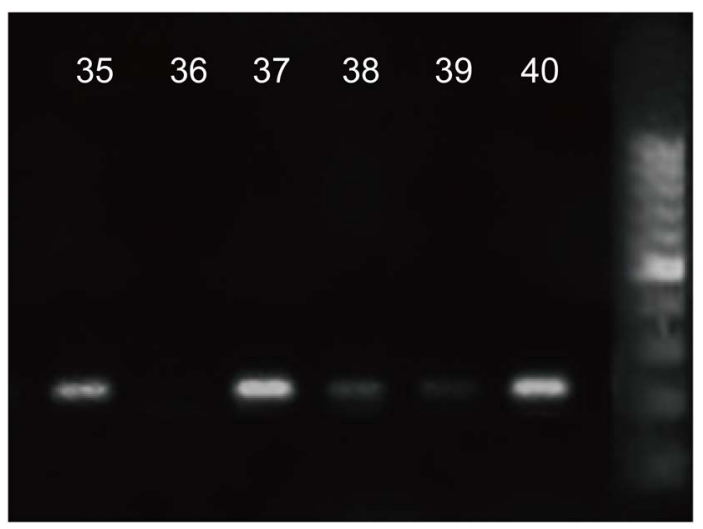

Figure 15. Confirmation of Tri5 gene in Fusarium solani.

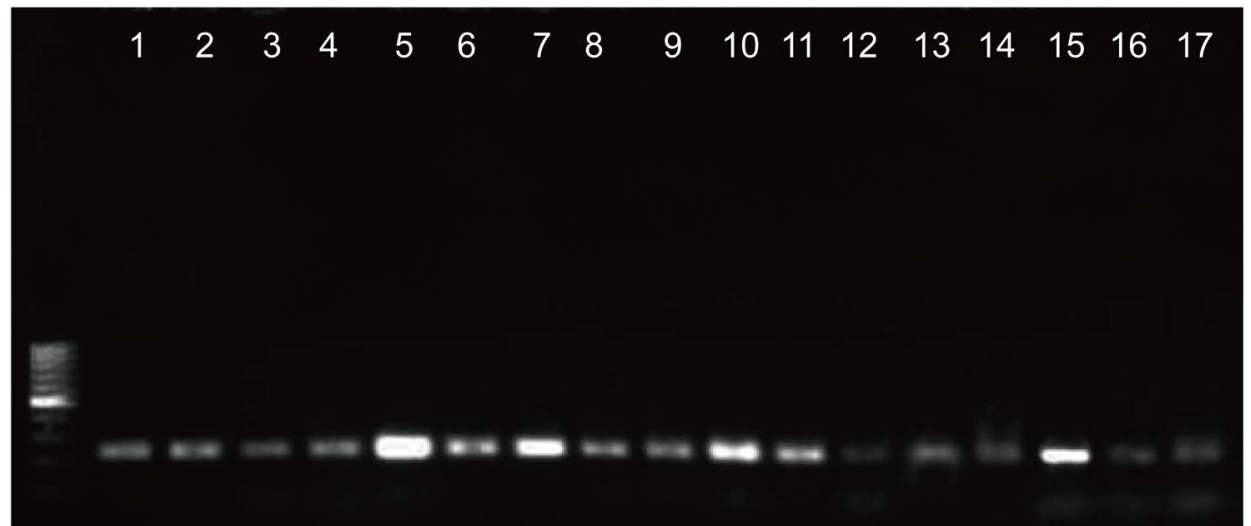

Figure 16. PCR photograph for DON producing F. solani. 


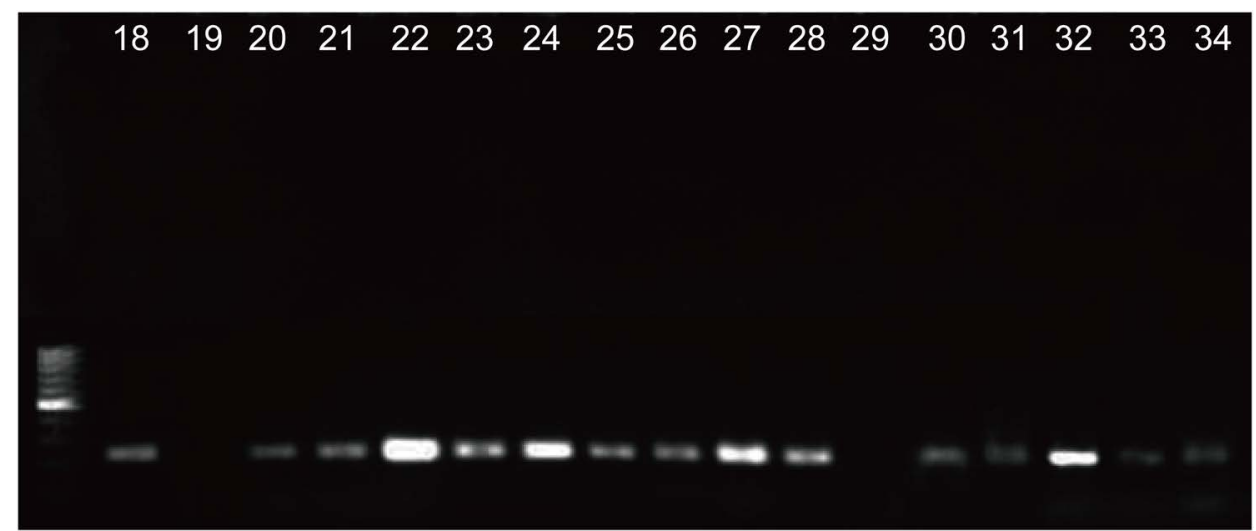

Figure 17. PCR photograph for DON producing Fusarium solani.

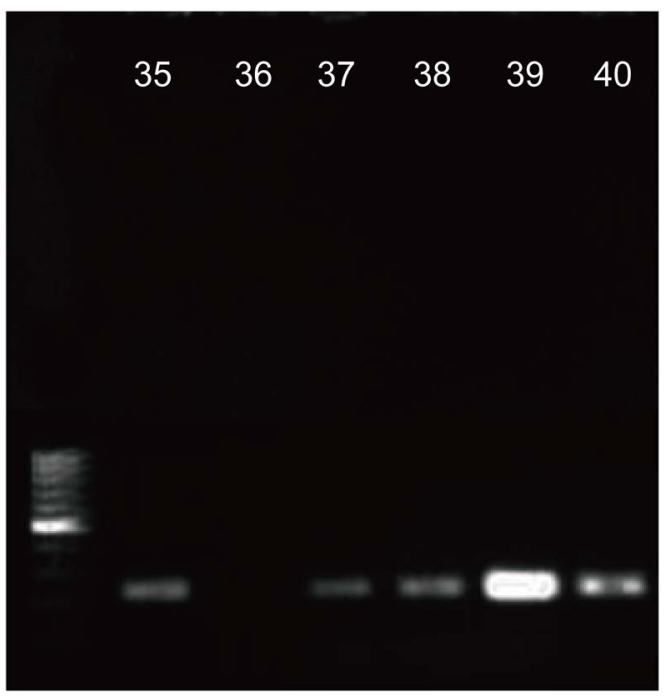

Figure 18. PCR photograph for DON producing Fusarium solani.

profile (shoot and root length, leaf area) and biochemical attributes (chlorophyll, carbohydrate and protein contents, antioxidant enzymes).

In this study, we analyzed the inhibition effect of different NPs (AgNPs, MgNPs, and chemical (Phylex)) against plant pathogenic fungi in vitro. The results suggest that NPs are capable of inhibiting these pathogens; however, results vary according to the concentration and type of NPs applied to pathogens. Most fungi showed a high inhibition effect at a $150 \mathrm{ppm}$ concentration of silver nanoparticles. 2\%, 3\% ppm concentration of magnesium oxides nanoparticles and 3\% concentration of Phylex inhibition increased as the concentration of NPs increased. This could be due to the high density at which the solution was able to saturate and cohere to fungal hyphe and to deactivate plant pathogenic fungi; also the results confirm to the efficiency phylex in the direct impact on the fungi. In vivo, after treating melon seeds with nanoparticles (AgNPs, MgNPs) and chemical (Phylex), the results differences were identified among treatment based on the height plant, shoot fresh weight, shoot dry weight root fresh weight and dry weight; the positive control had the lowest height and weight and was significantly dif- 
ferent from all other treatments in all of the growth parameters, while the treatment (AgNPs, MgNPs, Phylex) had the more height and weight according to the height plant, shoot fresh, shoot dry, root fresh, and root dry. Safe management methods that pose less dangers to human and animals, with a focus on overcoming deficiencies of synthetic fungicides, and also NPs (AgNPs, MgNPs) with low toxicity and abroad spectrum of antimicrobial activity were also very effective against plant phytopathogenic fungi. The results from this study of the (AgNPs, MgNPs) antifungal effect are significant and the synthesized NPs may have an advantage compared with conventional fun.

\section{References}

[1] Armengol, J.C., Jose, M., Moya, M.J., Sales, R., Vicent, A. and Garcia-Jimenez, J., (2000) Fusarium solani f. sp. cucurbitae Race 1, a Potential Pathogen of Grafted Watermelon Production in Spain. EPPO Bulletin, 30, 179-183.

http://dx.doi.org/10.1111/j.1365-2338.2000.tb00875.x

[2] Desjardins, A.E. (2006) Fusarium Mycotoxins: Chemistry, Genetics, and Biology. APS Press, St. Paul.

[3] Le, A.T., Huy, P.T., Tam, L.T., Tam, P.D., Hieu, N. and Huy, T. (2011) Novel Silver Nanoparticles: Synthesis, Properties and Applications. International Journal of Nanotechnology, 8, 278-290. http://dx.doi.org/10.1504/IJNT.2011.038205

[4] Vaidyanathan, R., Kalishwaralal, K., Gopalram, S. and Gurunathan, S. (2009) NanosilverThe Burgeoning Therapeutic Molecule and Its Green Synthesis. Biotechnology Advances, 27, 924-937. http://dx.doi.org/10.1016/j.biotechadv.2009.08.001

[5] Kim, K.J., Sung, W.S., Moon, S.K., Choi, J.S., Kim, J.G. and Lee, D.G. (2008) Antifungal Effect of Silver Nanoparticles on Dermatophytes. Journal of Microbiology and Biotechnology, 18, 1482-1484.

[6] Tang, Z.-X. and Lv, B.-F. (2013) MgO Nanparticle as Antibacterial Agent Preparation and Activity. Brazilian Journal of Chemical Engineering, 31, 591-601. http://dx.doi.org/10.1590/0104-6632.20140313s00002813

[7] Kim, S.W., Jung, J.H., Lamsal, K., Kim, Y.S., Min, J.S. and Lee, Y.S. (2012) Antifungal Effects of Silver Nan Particles (AgNPs) against Various Plant Pathogenic Fungi. Microbiolo$g y, 40,53-58$.

[8] Sutton, B.C. (1980) The Coelomycetes. Fungi Imperfecti with Pycnidia, Acervuli and Stromata. CMI, Kew, 696 p.

[9] Soriano-Martin, M.L., Porras-Piedra, A. and Porras-Soriano, A. (2006) Use of Microwaves in the Prevention of Fusarium oxysporum f. sp. Melonis Infection during the Commercial Production of Melon Plantlets. Crop Protection, 25, 52-57. http://dx.doi.org/10.1016/j.cropro.2005.03.016

[10] Murray, H.G. and Thompson, W.F. (1980) Rapid Isolation of High Molecular Weight DNA. Nucleic Acids Research, 8, 4321-4325. http://dx.doi.org/10.1093/nar/8.19.4321

[11] Hong, S.Y., Kang, M.R., Cho, E.J., Kim, H.K. and Yun, S.H. (2010) Specific PCR Detection of Four Quarantine Fusarium Species in Korea. The Plant Pathology Journal, 26, 409-416. http://dx.doi.org/10.5423/PPJ.2010.26.4.409

[12] Mehl, H.L. and Epstein, L. (2007) Identification of Fusarium solani f. sp. cucurbitae Race 1 and Race 2 with PCR and Production of Disease Free Pumpkin Seeds. Plant Disease, 91, 1288-1292. http://dx.doi.org/10.1094/PDIS-91-10-1288

[13] Aboli Parizi, M., Moradpour, Y., Negahdari, M. and Rahimiy, G. (2014) Assessing Anti- 
fungal Effects of Magnesium Oxide Nanoparticles on "Oxysporum f. sp. Lycopersic", Pathogenic Agent of Tomato. Electronic Journal of Biology, 10, 59-63.

[14] Imada, K., Sakai, S., Kajihara, H., Tanaka, S. and Ito, S. (2015) Magnesium Oxide Nanoparticles Induce Systemic Resistance in Tomato against Bacterial Wilt Disease. Plant Pathology, 65, 551-560. http://dx.doi.org/10.1111/ppa.12443

[15] Razzaq, A., Ammara, R., Jhanzab, H.M., Mahmood, T., Hafeez, A. and Hussain, S. (2015) A Novel Nanomaterial to Enhance Growth and Yield of Wheat. Journal of Nanoscience and Technology, 2, 55-58.

[16] Hojjat, S.S. and Ganjali, A. (2016) The Effect of Silver Nanoparticle on Lentil Seed Germination under Drought Stress. International Journal of Farming and Allied Sciences, 5, 208212.

[17] Booth, C. (1971) Fusarium: Laboratory Guide to the Identification of the Major Species. The Common Wealth Mycological Institute, Kew, 237 p.

[18] Hohn, T.M. and Desjardins, A.E. (1992) Isolation and Gene Disruption of the Tox5 Gene Encoding Trichodiene Synthase in Gibberella pulicaris. Molecular Plant-Microbe Interactions, 5, 149-156. http://dx.doi.org/10.1094/MPMI-5-249

[19] Xue, H.L., Yang, B., Tang, Y.M., Ying, Z. and Yi, W. (2014) Effect of Cultivars, Fusarium Strains and Storage Temperature on Trichothecenes Production in Inoculated Potato Tubers. Food Chemistry, 151, 236-242. http://dx.doi.org/10.1016/j.foodchem.2013.11.060

\section{Submit or recommend next manuscript to SCIRP and we will provide best service for you:}

Accepting pre-submission inquiries through Email, Facebook, LinkedIn, Twitter, etc. A wide selection of journals (inclusive of 9 subjects, more than 200 journals)

Providing 24-hour high-quality service

User-friendly online submission system

Fair and swift peer-review system

Efficient typesetting and proofreading procedure

Display of the result of downloads and visits, as well as the number of cited articles

Maximum dissemination of your research work

Submit your manuscript at: http://papersubmission.scirp.org/

Or contact ajps@scirp.org 